\title{
Deploying Elemental Iodine in a Vapor Form to Disinfect Water and to Clear Biofilms
}

\author{
Petronella R. Hove ${ }^{1, *}$, Daniel Mobley ${ }^{2}$, Forgivemore Magunda ${ }^{1}$ and Douglas R. Call ${ }^{2}$ \\ 1 Department of Microbiology, Immunology \& Pathology, Colorado State University, Fort Collins, \\ CO 80523, USA; forgivemore.magunda@colostate.edu \\ 2 Paul G. Allen School for Global Animal Health, Washington State University, Pullman, WA 99163, USA; \\ dan.mobley@email.wsu.edu (D.M.); drcall@wsu.edu (D.R.C.) \\ * Correspondence: petronella.hove@colostate.edu; Tel.: +1-970 492-4249
}

Received: 3 April 2020; Accepted: 13 May 2020; Published: 16 May 2020

check for updates

\begin{abstract}
Traditionally, iodine has been delivered as a solution, tablet or resin to disinfect water. In this study we evaluated the " $\mathrm{I}_{2}$ vapor infusion" $\left(\mathrm{I}_{2} \mathrm{VP}\right)$ technology which passes an airstream through a matrix containing elemental iodine $\left(\mathrm{I}_{2}\right)$ to produce $\mathrm{I}_{2}$ vapor as an innovative method of iodine delivery for water disinfection. Pressured air was provided either by a compressor or hand pump. Testing was performed with water inoculated with either Gram-negative (Escherichia, Salmonella) or Gram-positive (Enterococcus) bacteria or with pre-formed Acinetobacter or Staphylococcus biofilms. Bacterial colony forming units were used to assess efficacy of the device. In distilled water all bacteria and biofilms were eliminated after brief exposures ( $<90 \mathrm{~s})$. Culturable bacteria were also eliminated from pond and municipal sewer water, but the technology was mostly ineffective against dairy lagoon water with high turbidity and organic particulate. Longer duration infusion and higher air volumes used to overcome interference from organic matter were also associated with higher concentrations of residual iodine. We conclude that $\mathrm{I}_{2}$ vapor infusion has the potential to be useful for emergency water treatment and potentially for reducing microbiological contamination of some waste streams.
\end{abstract}

Keywords: iodine; sanitation; elemental iodine; iodine vapor infusion; water treatment; wastewater treatment

\section{Introduction}

Unclean drinking water is an important source of pathogenic bacteria, viruses and protozoan parasites for 2.7 billion people worldwide, underscoring the need for innovative safe and effective water disinfecting methods [1]. Current methods of water disinfection broadly include physical or chemical treatment. Among the well-known chemical disinfectants are halogens, which include bromine, fluorine, chlorine and iodine. [2,3]. Of these iodine has been widely used because it is generally effective, simple, cost-efficient and its properties for water disinfection are well known [4].

Iodine has mainly been used in emergencies and by travelers [4,5]. Its use as a water disinfectant can be dated back to the early $1900 \mathrm{~s}$ when the military first developed a tablet formulation for use in the field [6]. Like all halogens, iodine is a biocide because it is a strong oxidant [4]. However, relative to other halogens, complexed iodine has greater chemical stability [7]. It is also less reactive with organic nitrogenous contaminants and can be retained at a higher residual concentration in water [7]. These characteristics mean that iodine residuals will persist longer and will be more stable in the presence of organic matter compared to chlorine, the other commonly used halogen for water disinfection $[6,8]$. Compared to chlorine, iodine also has a more acceptable taste in equipotent concentrations and it is effective over a wider $\mathrm{pH}$ range [9-11]. Although the exact mechanism of action is unknown, iodine is known to rapidly penetrate into microorganisms [12]. It targets aromatic $\mathrm{C}-\mathrm{H}$ functions, sulfur-containing amino acids (cysteine, methionine), and unsaturated fatty acids [13]. As a bactericidal 
agent, iodine likely penetrates bacterial cell walls, and it's killing mechanism is likely related to retardation of bacterial protein synthesis, disruption of electron transport, DNA denaturation or membrane destabilization [3]. In lipid enveloped viruses [14] it is presumed to attack the surface proteins and destabilize membrane fatty acids by reacting with unsaturated carbon bonds [15]. Povidone iodine has also been reported as an effective environmental microbicide in the inactivation of coronaviruses [16].

In water, iodine is minimally soluble $\left(0.03 \mathrm{~g} / 100 \mathrm{~g}\right.$ water at $\left.20^{\circ} \mathrm{C}\right)$ compared to other halogens [17]. When added to water, it may remain unchanged or it may hydrolyze into different species depending on temperature, $\mathrm{pH}$ and the initial concentration. These different species include hypoiodous acid $(\mathrm{HIO})$, iodide ion $\left(\mathrm{I}^{-}\right)$, hypoiodite ion $\left(\mathrm{IO}^{-}\right)$, triiodide ion $\left(\mathrm{I}_{3}^{-}\right)$, iodic acid $\left(\mathrm{HIO}_{3}\right)$ and iodate $\left(\mathrm{IO}_{3}{ }^{-}\right)[18]$. It also exists as the diatomic elemental molecule, $\mathrm{I}_{2}$, momentarily after being oxidized from iodide. Of the species formed, only $\mathrm{I}_{2}$ and $\mathrm{HIO}$ are capable of biocide activity $[8,9,17,19,20]$. A pH near neutral to mildly alkaline ( $\mathrm{pH} 7-7.5)$ allows for adequate levels of both elemental iodine and hypoiodous acid [7]. The other iodine species serve as "reservoirs" by providing a source for $\mathrm{I}_{2}$ [17].

For practical purposes, iodine is employed as an iodine solution (e.g., tincture of iodine, a $2 \%$ iodine solution) and as tablets containing iodine along with carrier and stabilizing agents to enhance dissolvability (e.g., Globaline, composed of tetraglycine hydroperiodide, sodium acid pyrophosphate and talc; [20]). Iodine resins have also been designed as solid-phase iodine disinfectants were water disinfection occurs through direct contact with the microorganism as water passes through iodine that is adsorbed onto the resin [4]. The same principle is used in the formulation of iodinated biocides where the degree of disinfection is determined by the availability and regulated release of free elemental iodine [21].

Based on these characteristics of iodine, we propose that presentation of elemental iodine in an un-complexed form coupled to a delivery method that maximizes distribution and interaction with the target microbes would offer significant and rapid antimicrobial activity in a fluid. We evaluated the effectiveness of an " $\mathrm{I}_{2}$ vapor infusion" $\left(\mathrm{I}_{2} \mathrm{VP}\right)$ technology that introduces free iodine into solutions via transitory air bubbles that contain $\mathrm{I}_{2}$ vapor [22] The $\mathrm{I}_{2} \mathrm{VP}$ technology is an adaptation of the iodine-infused aeration of elemental $\mathrm{I}_{2}$ for hull fouling prevention. This method uses an infusion of air bubbles containing $\mathrm{I}_{2}$ to prevent or reduce fouling by inactivating bacteria that create fouling matrixes [23]. The goal was to determine if $\mathrm{I}_{2} \mathrm{VP}$ was capable of general water disinfection by testing the killing of gram-positive and negative bacteria either in free solution or as biofilm communities. This was considered in water of varying quality. We used the technology in two forms; as a hand powered system for use in emergencies, and for applications relevant to both water and wastewater treatment.

\section{Materials and Methods}

\section{1. "I $I_{2}$ Vapor Perfusion" ( $\left.I_{2} V P\right)$ System}

The $I_{2}$ fluid innovation system used in this study is a derivation of the device created by $I_{2}$ Air Fluid Innovation as a method for airstream, fluid and vessel decontamination, (Radicone and Miller 2008) [22]. Air was delivered to the I2VP system by either an electric compressor or hand pump. The airstream was first directed to a heater element (Figure 1A, ii.) warmed to $90{ }^{\circ} \mathrm{F}$ to increase sublimation of iodine. The amount of air entering the unit was controlled by a manual valve that was fixed to one position for all the experiments. From the heater element, air then entered the iodine resin encased in a cartridge. (Figure 1A, iii.). The iodine cartridge comprises of an air-inlet portion, through which air enters. The column of the cartridge is packed with beaded iodine resin. As air passes from the air-inlet portion, into the column, the iodine resin rapidly sublimates iodine ions into the air passing through the column and exists at the distal end connected to a tube. Iodine vapor is then delivered by the tube into a bubble forming element at the bottom of the container (Figure 1B-D) with water to be disinfected. The bubble forming element is constructed from a porous material and 
provides active bubble formation. The iodine-laden air bubbles sublimate the iodine into the fluid treating microbial contamination that may be present in the fluid [22].

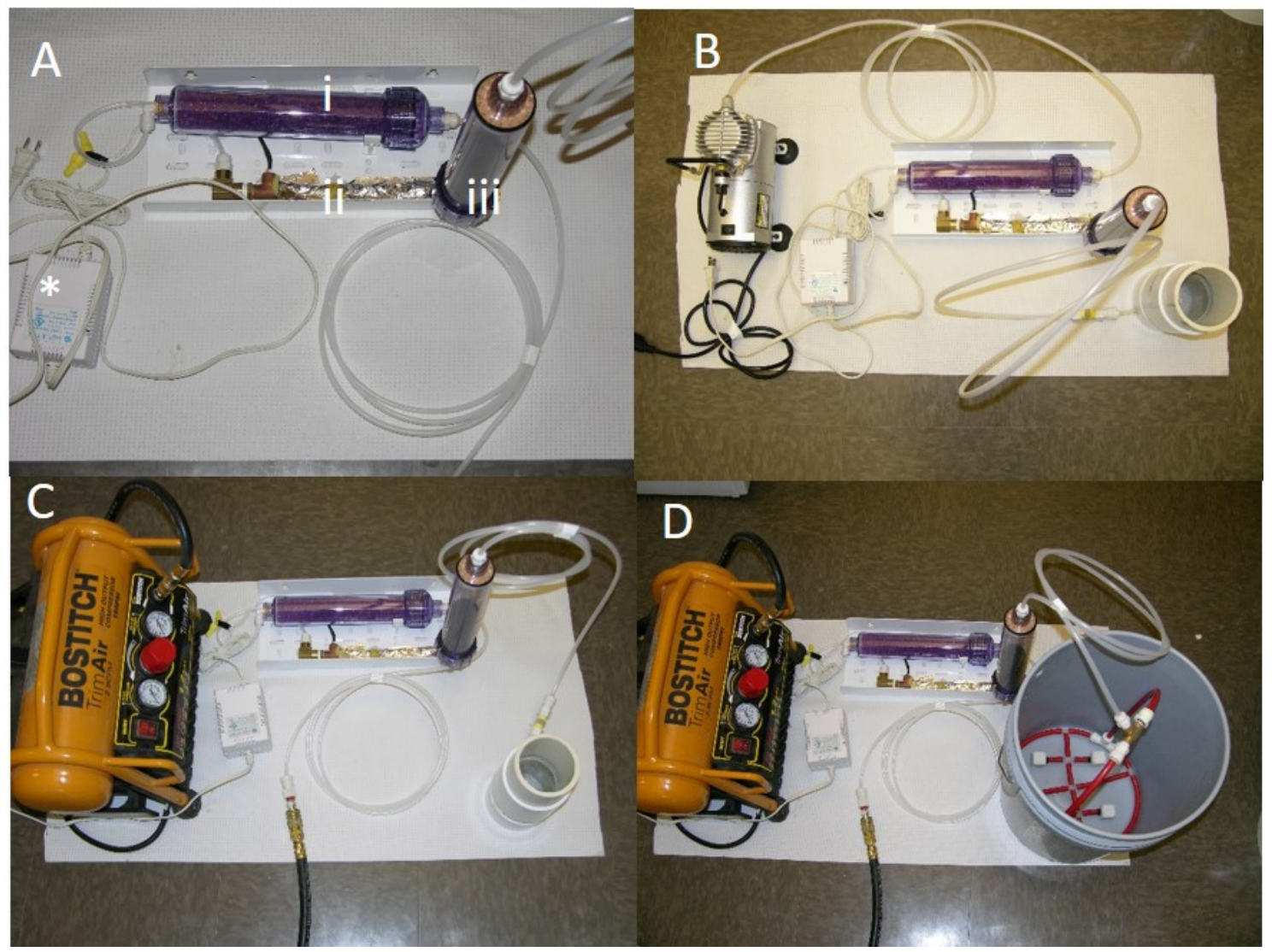

Figure 1. $\mathrm{I}_{2}$ vapor infusion $\left(\mathrm{I}_{2} \mathrm{VP}\right)$ system with different electric powered compressors. (A) Basic components of the $\mathrm{I}_{2} \mathrm{VP}$ system. Order taken by air (i) cartridge with moisture trapping beads (ii) heated tube to warm up air (iii) cartridge containing iodine coated resins. (B-D) various configurations of the $\mathrm{I}_{2} \mathrm{VP}$ diffuser System. (B) Air supplied by a lower capacity pump, Gilford Vacuum Pump (115V $60 \mathrm{~Hz} 2.3 \mathrm{~A}, 58 \mathrm{max}$ psi) attached to a $250 \mathrm{~mL}$ cylinder. (C) Air supplied by the higher capacity Bostitch trim Air 2.8CFM High Output compressor attached to a $250 \mathrm{~mL}$ cylinder. (D) Air supplied by the Bostitch trim Air 2.8CFM High Output compressor attached to a 5-gallon bucket. * 48-volt transformer.

For the compressor system (Figure 1) air was supplied through a low-capacity compressor, Gilford Vacuum Pump (115V 60Hz 2.3A, 58 max psi) attached to a $250 \mathrm{~mL}$ cylinder (Figure 1B).

For the experiments described this compressor was operated at maximum (58 psi). A high-capacity Bostitch trim Air 2.8CFM High Output compressor attached to a $250 \mathrm{~mL}$ cylinder or 5-gallon bucket. This compressor was operated between (75-100 psi).

The hand powered (bucket) system (Figure 2). Following initial testing with the electric system we adapted the iodine cartridge to a simple, hand-powered "bucket system" to determine if the technology could be scaled for use in households that lack access to potable water and electricity. The same iodine cartridge design was used for both the electric and hand powered system. Through the action of the hand pump ambient air was passed through the cartridge and delivered into a 5-gallon bucket through a coiled tube diffuser. Air was not pre-warmed with the bucket system. For the bucket system, the total volume of water used was approximately $3 \mathrm{~L}$. 


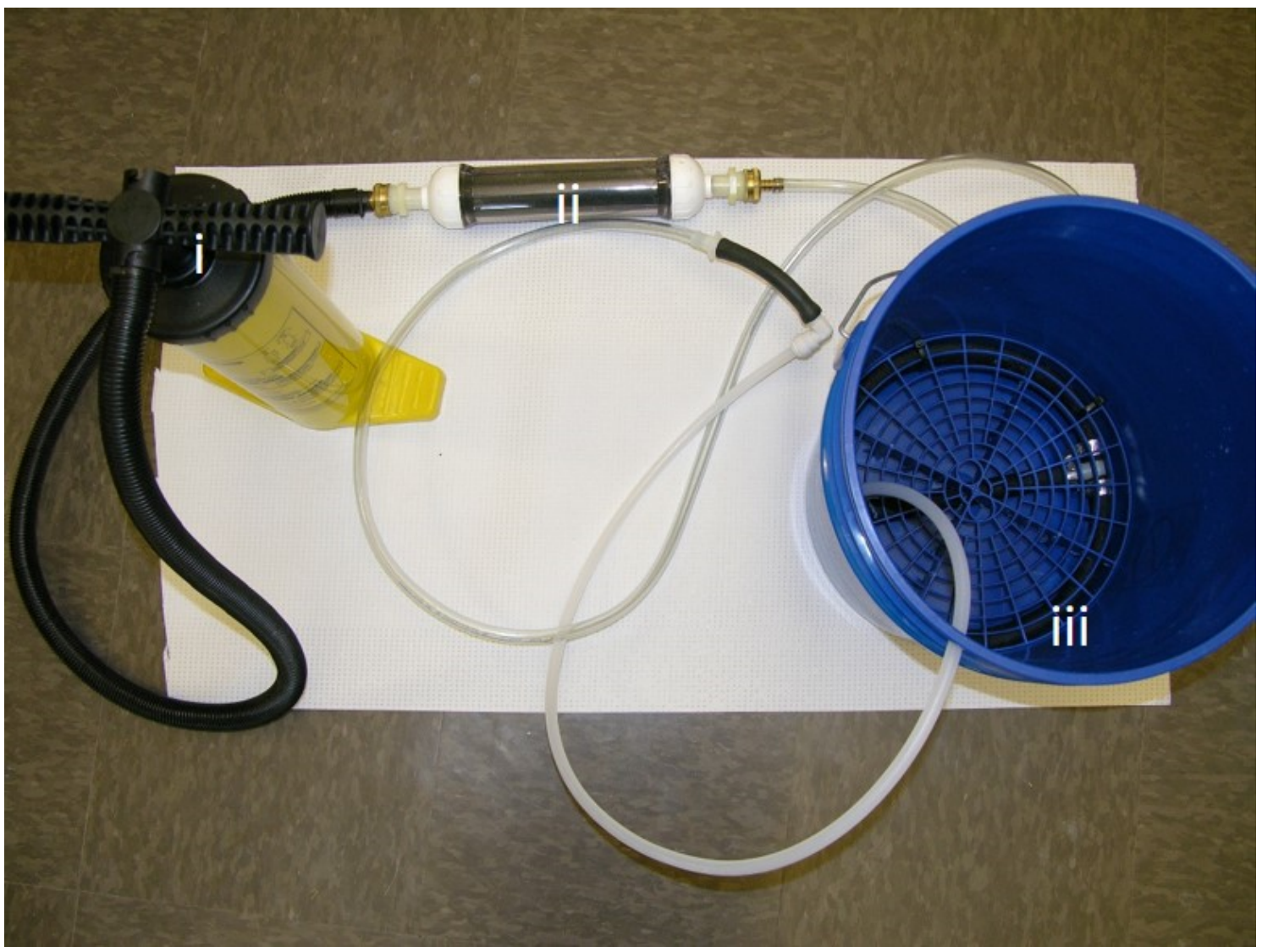

Figure 2. Configuration of the $\mathrm{I}_{2} \mathrm{VP}$ manually powered 'bucket system'. A hand pump (i) attached to the cartridge (ii) containing iodine coated resin. When air is pumped through the resin, vaporized elemental iodine is forced through a tube that connects to a coil diffuser system (iii) at the bottom of a 5-gallon bucket.

\subsection{Experimental Set Up}

Three configurations were used with the two different compressors (Figure 1), and a fourth configuration deployed a hand-operated recreational inflation pump (Figure 2). Experiments were done in increasing level of air pressure and decreasing water quality as determined by visual inspection. The first configuration used the low capacity compressor Gilford vacuum pump (115V 60Hz 2.3A, $58 \mathrm{psi})$ attached to a $250 \mathrm{~mL}$ cylinder with distilled water (i) inoculated with common water pathogens and biofilms and (ii) distilled water plus loess soil to simulate water of low quality containing organic matter (Figure 1B). The total carbon (TC) content was determined with a Leco CNS analyzer (Leco, St. Joseph, MI, USA) described previously [24]. No carbonates were detected, and soil was measured to have a total organic content of $2.27 \%$. The second configuration used the high capacity compressor Bostitch trim Air 2.8CFM High Output compressor (75-100 psi) attached to a $250 \mathrm{~mL}$ cylinder (Figure 1C) and centrifuged water (with particulate matter removed) from a diary lagoon. The third configuration was composed of the high capacity compressor attached to a 5-gallon bucket and was used to treat water from naturally occurring water bodies (pond, sewer and lagoon) to simulate use of the technology in real settings with high particulate matter or organic matter. The fourth configuration used a hand pump to treat (i) distilled water inoculated with common water pathogens (ii) water from naturally occurring water bodies to simulate use in low resource settings (water was inoculated with pathogenic bacteria to reach high bacterial load). Summary of the experimental set up is shown in Figure 3. 


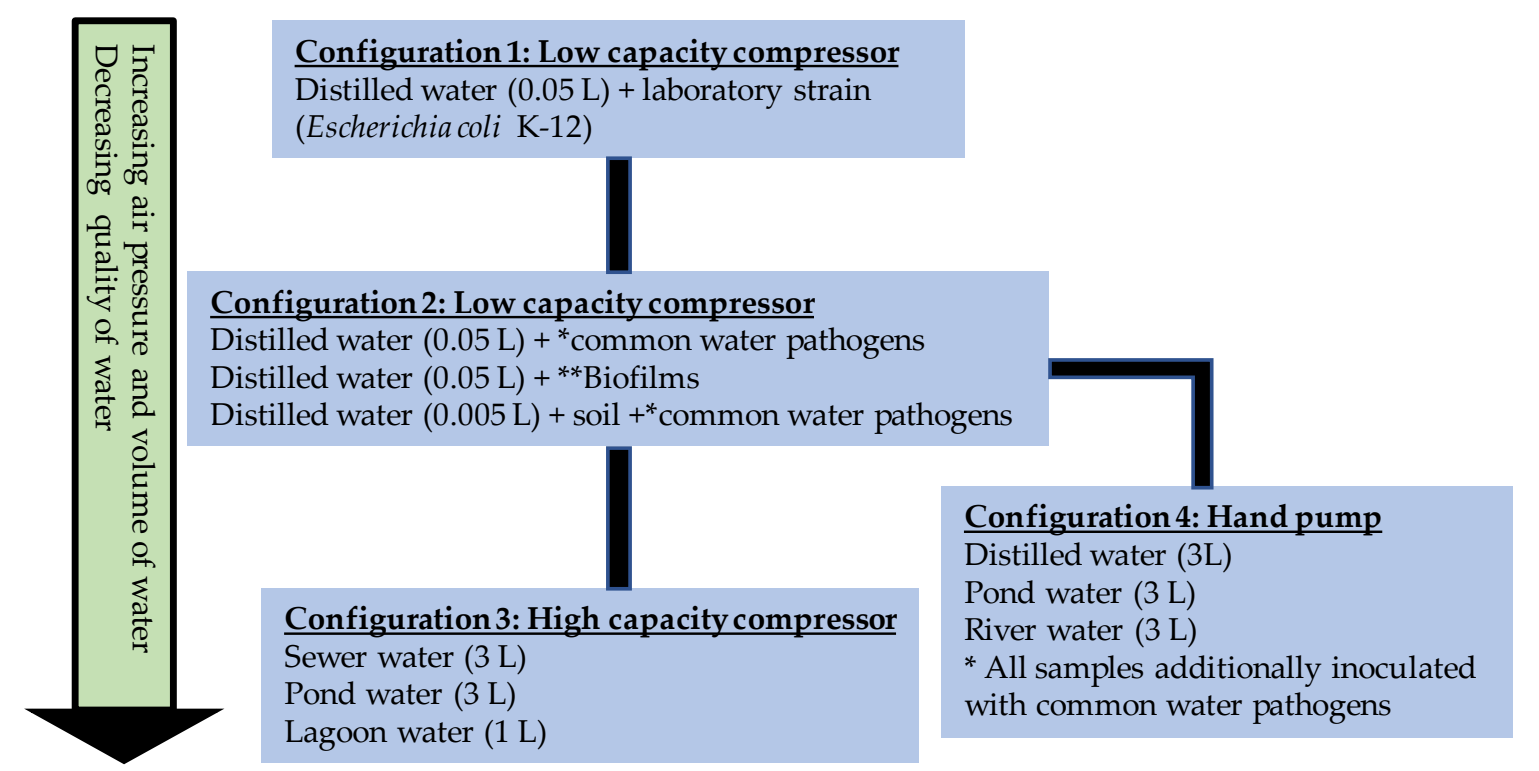

Figure 3. List of experimental setups for the disinfection of bacteria contaminated water using vaporized iodine. Configurations 1 is a proof of concept using water inoculated with a laboratory strain. Configurations 2 to 4 were setup to determine disinfecting efficacy of compressors delivering increasing air pressure and volume of water in disinfecting water of decreasing quality. ${ }^{*}$ Bacterial pathogens tested are Escherichia coli O157:H7, Enterococcus faecalis, Salmonella enterica ** Biofilms composed of Acinetobacter baumannii, Staphylococcus aureus.

\subsection{Bacterial Strains, Inoculation, Conditions and Enumeration}

Bacteria causing diseases transmitted through water were tested, these included two Escherichia coli strains, E. coli O157:H7 ((RIMD 0509952) (Sakai strain; $[25,26])$ a concern in outbreaks involving consumption of drinking water contaminated with human sewage or cattle feces. A lab adapted strain, nalidixic-resistant E. coli $\mathrm{K} 12$ (E. coli $\mathrm{K} 12 \mathrm{Nal}^{\mathrm{R}}$, [27]) was included as a control. Salmonella enterica serovar Typhimurium $[28,29]$ an environmental contaminate, commonly found in municipal sewage, agriculture pollution, and storm water; Enterococcus faecalis an important opportunistic pathogen frequently found in water [30]. Two biofilm producing strains, multi-drug resistant Acinetobacter baumannii (ATCC BAA-1605) and methicillin-resistant Staphylococcus aureus (ATCC BAA-1747) were also included. Strains were tested independently in each experimental run.

Bacteria were cultured overnight, and the resulting optical density was measured at $600 \mathrm{~nm}\left(\mathrm{OD}_{600}\right)$ to estimate colony forming units ( $\mathrm{cfu}) \mathrm{mL}^{-1}$ and then inoculated into water at a final concentration of approximately $10^{6} \mathrm{cfu} \mathrm{mL}^{-1}$ (to ensure a high concentration of bacteria). Before inoculation, cultures were centrifuged at 3000x $\mathrm{g}$ for $15 \mathrm{~min}$ and washed two times by re-suspending in $1 \mathrm{X}$ Dulbecco's Phosphate Buffered saline (PBS; MP Biomedicals LLC, Solon, OH, USA). Inoculum was added directly to water. Before treatment $2 \mathrm{~mL}$ samples were collected to determine starting $\mathrm{cfu} \mathrm{mL}^{-1}$. Water was then treated with iodine using the $\mathrm{I}_{2} \mathrm{VP}$ system.

After treatment, $2 \mathrm{~mL}$ water samples were collected to determine colony forming units (cfu) $\mathrm{mL}^{-1}$. Serial dilutions were prepared and $\mathrm{cfu} \mathrm{mL}^{-1}$ was estimated by using a 6 X6 drop-plate method [31]. Lennox Broth (LB) (Becton, Dickinson and Company, Franklin Lakes, NJ, USA) agar with nalidixic acid (32 $\mu \mathrm{g} \mathrm{mL}{ }^{-1}$; MP Biomedicals LLC, Solon, $\mathrm{OH}, \mathrm{USA}$ ) was used to enumerate nalidixic-resistant E. coli $\mathrm{K} 12 \mathrm{Nal}^{\mathrm{R}}$. LB agar without antibiotic was used to enumerate E. coli O157:H7. mEnterococcus broth (Becton, Dickinson and Company, Franklin Lakes, NJ, USA) agar plates were used to enumerate Enterococcus faecalis. Xylose lysine deoxycholate agar (XLD agar; Hardy Diagnostics, Santa Maria, CA, USA) was used to enumerate Salmonella. Unless noted otherwise, experiments were independently repeated three times. To assess the potential for use in turbid liquids, E. coli $\mathrm{K} 12-\mathrm{Nal}^{\mathrm{R}}\left(10^{6} \mathrm{cfu} \mathrm{mL}^{-1}\right)$ 
(in $5 \mathrm{~mL}$ sterile water) was mixed with $5 \mathrm{~g}$ of loess soil [24] before or after iodine perfusion, followed by bacterial quantification.

For the bucket system the same strains and final concentrations were used. Ambient air was moved through the cartridge and diffuser by hand pumping for 2 min followed by a 5 min break and then for 2 additional min. After treatment, a $2 \mathrm{~mL}$ sample was used for bacterial enumeration. Total cfu counts were determined after each two-minute pumping session. The system was rested and after $24 \mathrm{~h}$, a sample was collected before adding respective bacterial strains again at $10^{6} \mathrm{~mL}^{-1}$. After 5 min water samples were again collected for enumeration. The latter procedure was used to determine residual activity of iodine species after $24 \mathrm{~h}$.

\subsection{Biofilm Treatment}

To assess the efficacy of the $\mathrm{I}_{2} \mathrm{VP}$ technology on antimicrobial resistant and biofilm forming bacteria, Acinetobacter baumannii (ATCC BAA-1605) and Staphylococcus aureus (ATCC BAA-1747) biofilms were grown separately for $24 \mathrm{~h}$ in $3 \mathrm{~mL}$ of LB broth. Cultures were incubated in $16 \mathrm{~mL}$ polystyrene tubes and grown without shaking at $\left(37^{\circ} \mathrm{C}\right)$. The LB broth was decanted and biofilms were rinsed by gently mixing with sterile water $(4 \mathrm{~mL})$. Rinse water was decanted, and the bottom $1 \mathrm{~cm}$ of each plastic tube was cut to yield an open-ended column. Control biofilm communities were harvested for enumeration by first inserting the $16 \mathrm{~mL}$ open-ended tube into a $50 \mathrm{~mL}$ polypropylene tube. Ten sterile glass beads and $3 \mathrm{~mL}$ of LB agar were added directly to the $16 \mathrm{~mL}$ tube and the entire apparatus was vortexed for $60 \mathrm{~s}$ to dislodge and disrupt any biofilm from the surface of the $16 \mathrm{~mL}$ tube. Cfu counts were conducted as described above. Immediately after rinsing, biofilm communities from the no-treatment tubes were vortexed and enumerated. Remaining treatments involved submersion of the biofilm tubes into $45 \mathrm{~mL}$ water within a $250 \mathrm{~mL}$ cylinder. Air with or without iodine vapor was passed through the system so that the biofilm communities were directly exposed to $I_{2}$ vapor for $90 \mathrm{~s}$. Vortexing with sterile beads and enumeration followed as described above.

\subsection{Direct Infusion into Untreated Municipal Wastewater}

To test applicability of the device as an alternative method of municipal water treatment, raw wastewater (sewer water) was collected from a municipal wastewater treatment plant (Pullman, WA, USA). Water was collected after removal of solid waste at the plant. A Bostitch trim Air 2.8CFM High Output compressor was used to move air through the iodine matrix followed by diffusion into 3- $\mathrm{L}$ wastewater samples $(n=3)$ for 2, 4, 8 and $16 \mathrm{~min}$. The bucket was thoroughly cleaned with $70 \%$ ethanol between each treatment. After treatments serial dilutions were prepared and $\mathrm{cfu} \mathrm{mL}^{-1}$ was estimated by using a 6 X6 drop-plate method (see above).

\subsection{Infusion into River and Pond Water}

To assess efficacy of the device to clear naturally occurring bacteria from natural water bodies, we used pond and river water. We used the Bostitch trim Air 2.8 CFM High Output compressor with pumping for 2, 4, 8 and 16 min followed by enumeration by using both LB and MacConkey agar plates (Hardy Diagnostics, Santa Maria, CA, USA). MacConkey agar plates were used to selectively detect lactose and non-lactose fermenting Gram-negative bacteria. The same water samples were also treated using the hand pump. To challenge this system water was inoculated with three of the mentioned bacterial strains E. coli K-12, Salmonella enterica and Enterococcus faecalis as described above. 


\subsection{Infusion of Iodine Vapor into Dairy Lagoon Water}

To assess the feasibility of using iodine to treat agricultural water, we collected water from the animal waste lagoon at Knott's Dairy, Washington State University, Pullman, WA. Water was divided into two groups containing $20 \mathrm{~mL}$ aliquots. Water from the first group was sieved to remove bulk debris and then centrifuged at $3000 \mathrm{x} g$ for $15 \mathrm{~min}$ with the supernatant being subsequently treated as described above. The second group was not centrifuged. Experiments were conducted using the Bostitch trim Air 2.8 CFM High Output compressor with pumping for 4 and $8 \mathrm{~min}$ (air alone or with iodine vapor) followed by enumeration by using both LB and MacConkey agar plates (Hardy Diagnostics, Santa Maria, CA, USA). MacConkey agar plates were used to selectively detect lactose and non-lactose fermenting Gram-negative bacteria. This experiment was then repeated with $1 \mathrm{~L}$ of lagoon water to observe the effect of volume and continuous iodine exposure on bacteria recovery. Pumping was extended to $16 \mathrm{~min}$.

\subsection{Iodine Residue Testing}

Water samples were collected, before pumping, at 2 and $4 \mathrm{~min}$, and $24 \mathrm{~h}$ after infusion of iodine by either the compressor or hand pump in $25 \mathrm{~mL}$ glass tubes that were filled completely to exclude any air. These samples were then shipped by overnight courier to the Diagnostic Center for Population and Animal Health at Michigan State University for quantification of iodine species by using gas chromatography.

\section{Results}

\subsection{Iodine Infusion is Effective Against Gram-Negative and-Positive Bacteria}

The low capacity compressor attached to the $250 \mathrm{~mL}$ cylinder was used for initial testing. We considered two modes of operation including "pre-infusion of iodine" before introduction of bacteria, or infusion after introduction of bacteria. Pre-infusing distilled water with iodine before adding approximately $\left(10^{6} \mathrm{cfu} \mathrm{mL}^{-1}\right)$ bacteria was sufficient to kill all four of the strains after only $90 \mathrm{~s}$ exposure (Table S1). However, since this had no practical applicability, in all experiments, unless stated, iodine treatment was done after addition of inoculum. When ambient air was infused without iodine, bacterial counts were within $0.2 \mathrm{log} \mathrm{cfu} \mathrm{mL}^{-1}$ of the estimated inoculum value. When water with bacteria was infused directly with iodine, complete killing (6 log reduction) was observed with as little as $10 \mathrm{~s}$ infusion (Figure 4, left panel). The cfu $\mathrm{mL}^{-1}$ used to determine log reduction was estimated by using a 6 X6 drop-plate method with a limit of detection between $7-18 \mathrm{CFU} / \mathrm{mL}^{-1}$ [32]. To test the effectiveness of iodine treatment in the presence of organic material, water was mixed with a sample of loess soil and bacterial inoculum was added before or after iodine infusion. Most of the E. coli $\mathrm{K} 12-\mathrm{Nal}^{\mathrm{R}}$ was recovered after being mixed into the water-soil slurry that was pre-infused with iodine for $90 \mathrm{~s}$ (Table S1). Iodine treatment after addition of inoculum, however, completely removed the bacteria that were mixed with a starting inoculum of approximately $6 \log$ cfu $\mathrm{mL}^{-1}$ (Table S1). 

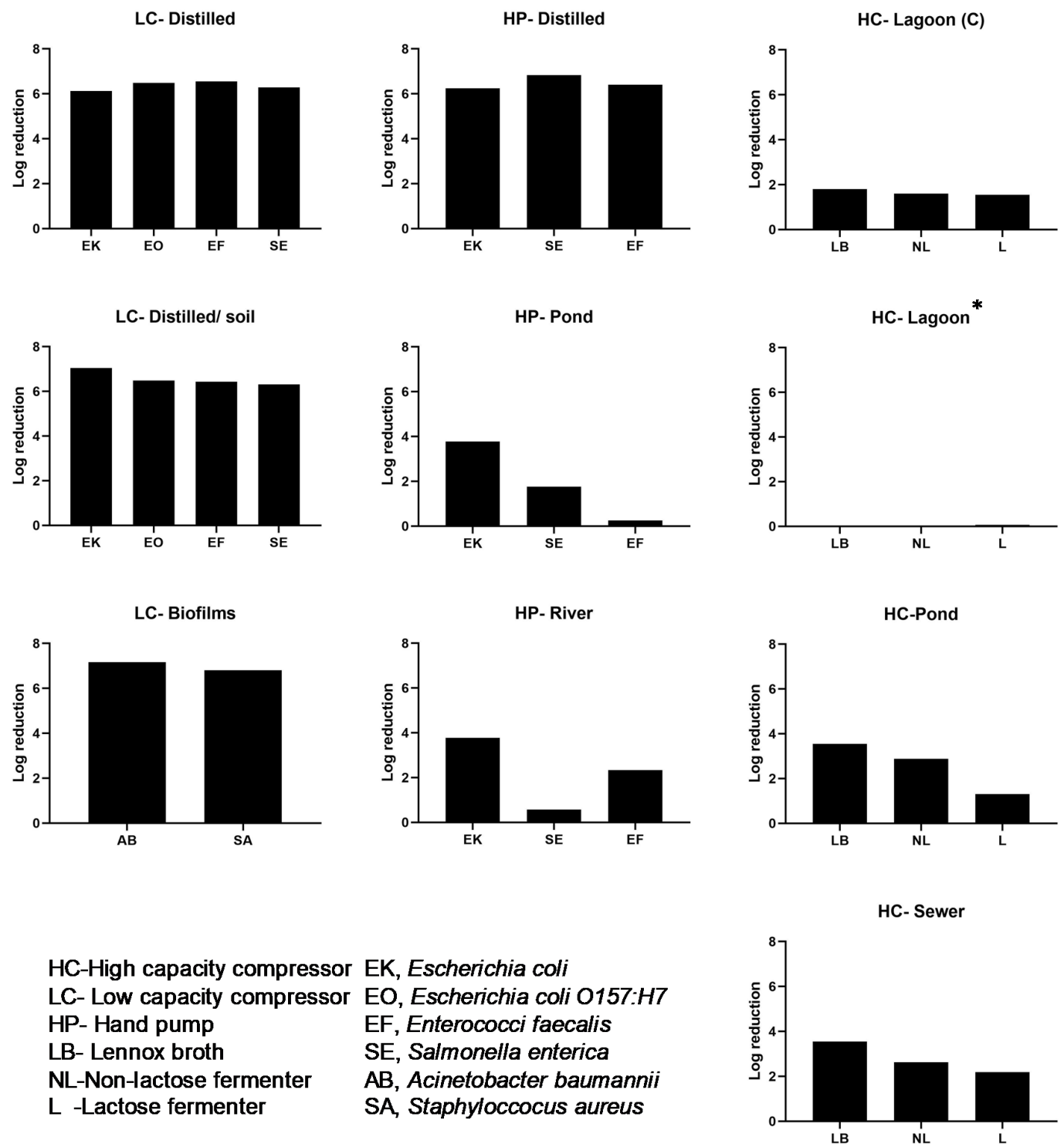

Figure 4. Log reduction following iodine treatment. Left panel: results after use of the low capacity compressor configuration to treat distilled water (LC-Distilled) inoculated with common water pathogens, distilled water plus loess soil (LC-Distilled/soil) and distilled water with biofilms (LC-Biofilms). A $6 \mathrm{log}$ reduction of pathogens was observed using this system. Middle panel: results after use of hand pump configuration to treat distilled water (HP-Distilled), water from naturally occurring water bodies (HP-Pond) and (HP-River) inoculated with and common water pathogens. Organic content in pond and river water reduced efficacy of the device. Right panel: high capacity compressor configuration was used to treat water from naturally occurring water bodies (lagoon (HC-lagoon (centrifuged) and (HC-lagoon) pond (HC-pond) and sewer (HC-Sewer)) to simulate use of the technology in real settings with high particulate matter or organic matter. Even in the presence of increased iodine concentration organic matter still reduced efficacy of iodine. ${ }^{*} \mathrm{cfu} \mathrm{mL}^{-1}$ used to determine log reduction was estimated by using a 6X6 drop-plate method with a limit of detection between 7-18 CFU/ $\mathrm{mL}^{-1}$.

\subsection{Iodine Infusion Eliminated Biofilm Communities}

The low capacity configuration was also able to sterilize inoculum of biofilm forming multi-drug resistant Acinetobacter baumannii and methicillin resistant Staphylococcus aureus, important hospital pathogens by a 6-log reduction (Figure 4, left panel). To determine if infused iodine bubbles affects biofilm communities, A. baumannii and S. aureus biofilms were grown for $24 \mathrm{~h}$ as static cultures. 
Untreated A. baumannii biofilm yielded $7.16 \log \mathrm{cfu} \mathrm{mL} L^{-1}$ that was reduced to $5.32 \log \mathrm{cfu} \mathrm{mL} \mathrm{m}^{-1}$ from air infusion alone (presumably due to shear force). Infusion with iodine vapor resulted in complete loss of $A$. baumannii after a brief (90 s) exposure (Table S1). Results for $S$. aureus biofilms were similar, with some loss of bacteria from air infusion alone (6.81 to $\left.6.14 \mathrm{cfu} \mathrm{mL}^{-1}\right)$, but complete loss of recoverable bacteria when infused with iodine vapor (Table 1$)$.

Table 1. Iodine residues following hand pump and compressor delivered iodine vapor.

\begin{tabular}{ccc}
\hline System Used & Condition & ug $\mathbf{~ m L}^{-\mathbf{1}} \mathbf{~}(\mathbf{p p m})$ \\
\hline Bucket system (3-L vol.) & No infusion & 0 \\
& 2 min infusion & 0.082 \\
& 4 min infusion & 0.183 \\
& 24 h after 4 min infusion & 0.159 \\
Compressor (3-L vol.) & 4 min infusion & 1.42 \\
& 8 min infusion & 2.19 \\
& 16 min infusion & 3.47 \\
Compressor (50 mL vol.) & 24 h after 16 min infusion & 1.33 \\
& 4 min infusion & 8.46 \\
& 8 min infusion & 9.52 \\
& 16 min infusion & 12 \\
\hline
\end{tabular}

${ }^{a}$ Value is an average of three experimental replicates.

For the hand-operated bucket system, water inoculated with E. coli $\mathrm{K} 12-\mathrm{Nal}{ }^{\mathrm{R}}$, Salmonella, or Enterococcus strains (Figure 4, middle panel) was exposed to air with and without iodine vapor treatment. For the volume treated $(3 \mathrm{~L})$ and inoculum present (app. $10^{6} \mathrm{cfu} \mathrm{mL}^{-1}$ ), infusion for 4 min was enough to completely sanitize the water of all bacteria that had been added (Table S2). Iodine-treated water remained sterile for at least $24 \mathrm{~h}$. Subsequent addition of Enterococcus faecalis $\left(8.58 \mathrm{log} \mathrm{cfu} \mathrm{mL} \mathrm{m}^{-1}\right)$ or S. enterica $\left(9.87 \mathrm{cfu} \mathrm{mL}^{-1}\right)$ to $24 \mathrm{~h}$ post-treated water resulted in only a limited reduction (approximately 2-log) in viable cells after $5 \mathrm{~min}\left(6.38\right.$ and $7.03 \log \mathrm{cfu} \mathrm{mL} \mathrm{L}^{-1}$, respectively). Suggesting that residual iodine species were not high enough to maintain disinfection. For the bucket system, pond and river water were used to represent examples of undefined organic matter contamination. Given a volume of $3 \mathrm{~L}$ and up to $16 \mathrm{~min}$ hand pumping, bacterial counts were reduced 0.58 to $3.77 \log$ cfu mL $\mathrm{mL}^{-1}$ from starting inoculum of approximately $6 \log \mathrm{cfu} \mathrm{mL}^{-1}$ (Table S2). This suggests that organic matter limits the efficacy of iodine vapor.

\subsection{Wastewater Treatment Produced Variable Results}

After seeing reduced efficacy of iodine in low quality water, we decided to increase iodine concentration by using a high capacity compressor. Lagoon, pond and river water was used. We did not artificially inoculate the water but assessed naturally occurring bacteria. For this experiment we enumerated total bacteria on LB or MacConkey agar, with the latter being used to quantify lactose-fermenting or non-fermenting bacteria. Dairy lagoon wastewater was collected from a location where the water was manually agitated on a continuous basis resulting in a turbid sample with high organic load from sediment, fecal waste and other debris. Because lagoon water foamed, these experiments were conducted in a total volume of $20 \mathrm{~mL}$ ( $250 \mathrm{~mL}$ cylinder system) or $1 \mathrm{~L}$ (bucket with high-volume compressor). For the smaller volume of centrifuge lagoon water, total counts on LB did not change after an initial 1.8-log decrease, while counts using MacConkey agar did not decline $1.5 \log$ until after $16 \mathrm{~min}$ continuous bubbling (Table S3). For the larger volume of uncentrifuged lagoon water, iodine infusion had no effect (Figure 4, left panel). This shows that in the presence of increased iodine concentration organic matter still reduced efficacy of iodine.

Municipal wastewater was collected at the inlet at the public works and 3-L samples were treated for each experiment. Municipal wastewater (sewer) had far less suspended solids (visual inspection) and had relatively low bacterial counts $\left(\leq 3.5 \log\right.$ cfu $\left.\mathrm{mL}^{-1}\right)$ that were eliminated with as little as $4 \mathrm{~min}$ 
of iodine infusion (Table S3) (Figure 4, left panel). The pond water that we sampled had an initial bacterial count that was similar to municipal wastewater and was also eliminated with as little as $4 \mathrm{~min}$ of iodine infusion (Table S3).

\subsection{Iodine Residues after Iodine Infusion}

To test the iodine residue levels, water samples were collected before pumping 2 and $4 \mathrm{~min}$, and $24 \mathrm{~h}$ thereafter for the hand pumped bucket system. The maximum concentration of iodine was detected after $4 \mathrm{~min}\left(0.183 \mathrm{ug} \mathrm{mL}^{-1}\right)$, which decreased to $0.159 \mathrm{ug} \mathrm{mL}^{-1}$ after $24 \mathrm{~h}$ (Table 1$)$. When a 3-L.

Volume of water was infused by using an electric compressor, residues peaked at $3.47 \mathrm{ug} \mathrm{mL}^{-1}$ after 16 min of iodine infusion. Samples collected from a $50 \mathrm{~mL}$ volume of water (using the $250 \mathrm{~mL}$ cylinder system) had the highest concentration of residues (16 min infusion, $12 \mathrm{ug} \mathrm{mL}^{-1}$ iodine). As anticipated, iodine residues were dependent on the volume of water being treated and the volume of air with iodine that was passed through the water

\section{Discussion}

This study describes the potential application of a newly patented technology $\left(\mathrm{I}_{2} \mathrm{VP}\right)$ that delivers iodine vapor for water disinfection. The technology was effective when sterilizing distilled water that was inoculated with enteric organisms (Escherichia, Salmonella and Enterococcus). This worked well when distilled water was pre-infused with iodine before adding bacteria, but also when water was infused. In drinking water, coliforms, Escherichia coli and enterococci have been used as the primary method of assessing contamination (representative strains were used in this study [32]. We show that the I2VP would be effective in sterilizing these coliforms by a 6-log reduction. The device was also effective against drug resistant pathogens tested i.e., methicillin-resistant Staphylococcus and multi-drug resistant Acinetobacter biofilm communities. This is also consistent with published reports of its potential use in controlling biofouling or for sanitation of interior surfaces of hoses [22].

The last comprehensive study of the disinfection efficacy of iodine for water treatment showed that concentrations in the range 5-10 ppm were effective against different types of microorganisms within $10 \mathrm{~min}$ at room temperature [6], another group showed that iodine tablets needed a contact time of 5-25 min depending on temperature [11] and up to $30 \mathrm{~min}$ in the presence of organic matter [33]. In this study, we were able to show efficacy of less than $90 \mathrm{~s}$ at room temperature with residues of $12 \mathrm{ppm}$ with the electric power compressor and $4 \mathrm{~min}$ with residues less than $1 \mathrm{ppm}$ following use of the hand pump. The electric powered compressor was superior in terms of time and effort required to deliver $I_{2}$ vapor compared to the manual version. However, a 4 min pump time with the manual device was still less than half of the 10 min reportedly necessary to kill microorganism using aqueous iodine. Our findings suggest that the $\mathrm{I}_{2} \mathrm{VP}$ technology greatly reduces contact time necessary for water disinfection.

As has been also shown previously [33], application of this technology is limited when water contains a high level of suspended solids and organic materials such as manually agitated dairy waste lagoon water that we tested. The presence of natural organic substances is associated with iodine demand and reduced efficacy [7]. Even though this occurs, iodine shows appreciable lower reactivity when compared to chlorine, which is widely used for water disinfection [7]. Despite this limitation, we found the technology was effective against bacteria found naturally in municipal sewer water and in a sample of pond water provided that enough volume of $I_{2}$ vapor is introduced into the water column. Depending on the situation, pre-filtration using a gravity-feed sand filter or using flocculation could be used as simple methods to reduce the concentration of suspended particles prior to $I_{2}$ vapor treatment. Use of sequential UV radiation can also be considered as it has been shown to increase efficacy of chlorine in the presence of suspended solids [34]. Coupling iodine use with alternative disinfectants such as Peracetic acid (PAA) may also be explored [35]. 
We hypothesize that the technology works well because vaporized $I_{2}$ is protected within the air bubbles long enough to be dispersed throughout a water column where it diffuses into the water and interacts with bacterial membranes. If correct, this is also consistent with reduced performance with increasing load of dissolved solids with which the iodine can interact. It also suggests that there will be optimal performance conditions that match the rate of infusion with water volume and concentration of interfering contaminants. Others have shown that iodine disinfection can be very sensitive to organic nitrogenous contaminants $[10,11]$ and we surmise that the failures that we observed were due to the presence of organic compounds in the culture media. If correct, empirical testing will be needed to validate potential applications of this technology for different waste streams.

Hydrolysis and the subsequent equilibrium between elemental iodine and hypoiodous acid are $\mathrm{pH}$-dependent, but the effect is not as pronounced as with chlorine [6], which allow iodine to be used across a wide range of $\mathrm{pH}$. For our experiments the $\mathrm{pH}$ was neutral to mildly alkaline (pH 7-7.5), which is reportedly compatible with both elemental iodine and hypoiodous acid [7]. Elemental iodine is primarily effective against bacterial spores and protozoan cysts, whereas hypoiodous acid is known to be an effective bactericide and virucide [36]. We surmise that the $\mathrm{I}_{2} \mathrm{VP}$ technology can effectively deliver iodine to kill viruses and cysts, but this will need to be investigated further.

In addition, iodine is reportedly less reactive than chlorine and consequently chlorine is relatively less effective in the presence of organic material [37]. Because chlorine interacts with dissolved organic matter, it potentially forms harmful disinfection byproducts (e.g., trihalomethanes and haloacetic acids), most of which are regulated by the U.S. Environmental Protection Agency [37,38]. With respect to toxicity, recent research performed during a Navy Environmental Sustainability Development to Integration (NESDI) program compared the toxicity of aqueous chlorine and iodine by evaluating the relative effects on fertilization rates of the Trepnuestes gratilla, the Hawaiian collector sea urchin. Results were expressed as the no observable effect concentration (NOEC) and lowest observable effect concentration (LOEC). The NOEC for iodine and chlorine was $0.01 \mathrm{ppm}$ and $0.002 \mathrm{ppm}$, respectively, while the LOEC for iodine and chlorine was $0.014 \mathrm{ppm}$ and $0.003 \mathrm{ppm}$, respectively. These data are consistent with chlorine toxicity being an order-of-magnitude greater than that of iodine. Formation of DBPs from a number of iodine-based disinfectants was compared and it was found to be dependent on method of delivery method [39]. This report suggested that use of iodine tincture was associated with higher levels of iodoforms. This will require further investigation for the $\mathrm{I}_{2} \mathrm{VP}$ device. This suggests that perfecting iodine delivery will allow its use as a safer alternative to chlorine for water treatment.

Our results are consistent with scalability of the $\mathrm{I}_{2} \mathrm{VP}$ system, which is not surprising given that delivery and dispersion will be concentration and volume dependent. Larger diffusers, more air flow and longer exposures could be used to improve performance against larger volumes of water or when organic loads are higher. Nevertheless, under ideal conditions (i.e., with no visible contaminants) sanitation can be successful at a scale (3 L) that can be processed using a manually operated air pump for as little as $4 \mathrm{~min}$. Given longer exposures and smaller volumes, the total residue concentration increases; hand-pumped bucket system ( $0.183 \mathrm{ug} \mathrm{mL}^{-1}$ for $3 \mathrm{~L}$ and $\left.4 \mathrm{~min}\right)$, compressor pumped bucket system (3.47 ug mL $\mathrm{mL}^{-1}$ for $3 \mathrm{~L} ; 16 \mathrm{~min}$ ), $250 \mathrm{~mL}$ compressor cylinder (12 ug mL ${ }^{-1}$ for $250 \mathrm{~mL}, 16 \mathrm{~min}$ ).

Iodine is an essential nutrient required for development and functioning of the thyroid gland, but excess iodine may lead to thyroid disease $[40,41]$. Toxicity to iodine has been linked to genetic or physiological predisposition (Rose et al., 2002) and to the use of iodine-based products as disinfectants [4] and medications [42]. Earlier work suggested that consumption of conventionally iodinated drinking-water did not cause adverse health effects in people [43]. More recent reports indicate that iodine toxicity is uncommon [44] and people appear to have a high tolerance to iodine given doses $<2 \mathrm{mg} \mathrm{day}^{-1}$ [42]. The World Health Organization estimates that oral doses of 2000-3000 mg iodine (about 30-40 $\mathrm{mg} \mathrm{kg}^{-1}$ of body weight) are lethal to people [45] while chronic ingestion of $2 \mathrm{mg}$ of iodide per day $\left(0.03 \mathrm{mg} \mathrm{kg}^{-1}\right.$ of body weight per day) is considered excessive. Others have reported that daily doses of $50-80 \mathrm{mg}\left(0.8-1.3 \mathrm{mg} \mathrm{kg}^{-1}\right.$ of body weight per day) can be consumed without ill effect [46]. For the current study, if we assume that water consumption for an adult person is $4 \mathrm{~L} \mathrm{day}^{-1}$ 
then water prepared by using the hand-pumped bucket system would deliver a daily dose of $0.73 \mathrm{mg}$ of iodine that is well below suggested limits for chronic exposure. At the very least, the technology should be suitable for emergency water treatment in the absence of electricity assuming that the treated water has limited suspended solids. If higher air volume methods are used, real-time testing for iodine residues or secondary sequestration (e.g., activated charcoal) may be needed to guard against excessive iodine exposure.

The $\mathrm{I}_{2} \mathrm{VP}$ technology has also been tested elsewhere. A study funded by the US Navy demonstrated the potential for the patented $\mathrm{I}_{2}$ infusion system to reduce the rate of bio-fouling within Department of Defense shipboard heat exchangers [23,47]. For this project, periodic infusion of air containing elemental iodine vapor into the heat exchanger reduced the need for routine physical cleaning (which requires hazardous chemicals) while maintaining with acceptable operating parameters. Based on our findings, it is likely that this technology can be used for emergency and household drinking water treatment, sanitation of waste streams such as municipal sewage, and for managing biofilms that form within water lines that are used in food manufacturing and food animal agriculture.

\section{Conclusions}

Iodine infusion was effective against bacteria and biofilms even in water with moderate loads of suspended particles. It is unlikely to work well if treating waters containing high concentrations of dissolved solids (e.g., dairy lagoon water). The technology is relatively simple to implement and can be scalable for use as emergency water treatment and for reducing microbiological contamination of some waste streams such as municipal and hospital sewer lines. The technology is of low cost and we show that both an electric and hand operated version is effective in the absence of organic matter.

Supplementary Materials: The following are available online at http://www.mdpi.com/1660-4601/17/10/3489/s1, Table S1: Log cfu ml ${ }^{-1}$ before and after treatment for $90 \mathrm{~s}$ with the 250-mL cylinder system, Table S2: Log cfu mL $\mathrm{mL}^{-1}$ before and after treatment at respective times with hand-pump bucket system (3 L test volume), Table S3: Log cfu $\mathrm{mL}^{-1}$ of naturally occurring bacteria before and after treatment of different water samples (3 L fluid volume, high air volume).

Author Contributions: Conceptualization, D.R.C.; formal analysis, P.R.H. and D.M.; funding acquisition, D.R.C.; investigation, P.R.H. and D.M.; project administration, P.R.H.; supervision, D.R.C.; writing-original draft, P.R.H. and D.M.; writing-review and editing, P.R.H., F.M. and D.R.C. All authors have read and agreed to the published version of the manuscript.

Funding: This research received no external funding.

Acknowledgments: Lisa Orfe assisted with the lab worked reported in this manuscript. Michael Radicone, President and CEO of $\mathrm{I}_{2}$ Air Fluid Innovation invited DRC to conduct this independent assessment of the iodine vapor infusion technology. $\mathrm{I}_{2}$ Air Fluid Innovation provided the hardware that was used for these experiments and a sum of $\$ 3,500$ to cover consumable expenses. $I_{2}$ Air Fluid Innovation and its employees made no contribution to this publication.

Conflicts of Interest: The authors declare no conflict of interest.

\section{References}

1. United Nations Children's Fund and World Health Organization. Progress on Household Drinking Water, Sanitation and Hygiene 2000-2017: Special Focus on Inequalities; UNICEF and WHO: New York, NY, USA, 2019; pp. 1-71.

2. Brown, J.R.; McLean, D.M. Observations on Halogens as Bathing Water Disinfectants. J. Appl. Bacteriol. 1966, 29, 559-565. [CrossRef] [PubMed]

3. McDonnell, G.; Russell, A.D. Antiseptics and Disinfectants: Activity, Action, and Resistance. Clin. Microbiol. Rev. 1999, 12, 147-179. [CrossRef] [PubMed]

4. Backer, H.; Hollowell, J. Use of iodine for water disinfection: Iodine toxicity and maximum recommended dose. Environ. Health Perspect. 2000, 108, 679-684. [PubMed]

5. Ongerth, J.E.; Johnson, R.L.; Macdonald, S.C.; Frost, F.; Stibbs, H.H. Back-country water treatment to prevent giardiasis. Am. J. Public Heal. 1989, 79, 1633-1637. [CrossRef] 
6. Chang, S.L.; Morris, J.C. Elemental Iodine as a Disinfectant for Drinking Water. Ind. Eng. Chem. 1953, 45, 1009-1012. [CrossRef]

7. WHO. Alternative Drinking-Water Disinfectants: BROMINE, Iodine and Silver; WHO: Geneva, Switzerland, 2018; pp. 1-51.

8. Black, A.P.; Kinman, R.N.; Thomas, W.C.; Freund, G.; Bird, E.D. Use of Iodine for Disinfection. J. Am. Water Work. Assoc. 1965, 57, 1401-1421. [CrossRef]

9. Ericsson, C.D.; Steffen, R.; Backer, H. Water Disinfection for International and Wilderness Travelers. Clin. Infect. Dis. 2002, 34, 355-364. [CrossRef]

10. NRC. Drinking Water and Health; The National Academies Press: Washington, DC, USA, 1980; Volume 2, p. 408. [CrossRef]

11. O'Connor, J.T.; Kapoor, S.K. Small quantity field disinfection. J. Am. Water Work. Assoc. 1970, 62, 80-84. [CrossRef]

12. Chang, S.L. Modern concept of disinfection. J. Sanit. Eng. Div. ASCE 1971, 97, 689-707.

13. Gottardi, W. Iodine as Disinfectant. In Iodine Chemistry and Applications; Tatsuo, K., Ed.; Wiley: Hoboken, NJ, USA, 2014; pp. 375-410.

14. Prince, H.N.; Prince, D.L.; Prince, R.N. Principles of Viral Control and Transmission, 4th ed.; Lea \& Febiger: Philadelphia, PA, USA, 1991.

15. Springthorpe, V.S.; Sattar, S.A. Chemical disinfection of virus-contaminated surfaces. Crit. Rev. Environ. Control. 1990, 20, 169-229. [CrossRef]

16. Wolff, M.H.; Sattar, S.A.; Adegbunrin, O.; Tetro, J. Environmental survival and microbicide inactivation of coronaviruses. In Coronaviruses with Special Emphasis on First Insights Concerning SARS; Springer Science and Business Media LLC: Berlin, Germany, 2005; pp. 201-212.

17. Gottardi, W. Iodine and Iodine Compounds, 4th ed.; Lea \& Febiger: Philadelphia, PA, USA, 1991.

18. Gerba, C.P.; Johnson, D.C.; Hasan, M.N. Efficacy of iodine water purification tablets against Cryptosporidium oocysts and Giardia cysts. Wilderness Environ. Med. 1997, 8, 96-100. [CrossRef] [PubMed]

19. Chang, S.L. The use of active iodine as a water disinfectant. J. Am. Pharm. Assoc. Am. Pharm. Assoc. 1958, 47, 417-423. [PubMed]

20. Inactivation of Giardia Cysts by Iodine with Special Reference to Globaline: A Review. Available online: https://apps.dtic.mil/dtic/tr/fulltext/u2/a234938.pdf (accessed on 15 May 2020).

21. Gottardi, W. The influence of the chemical behaviour of iodine on the germicidal action of disinfectant solutions containing iodine. J. Hosp. Infect. 1985, 6, 1-11. [CrossRef]

22. Device and Method for Air Stream, Fluid and Vessel Decontamination. Available online: https://patents. google.com/patent/US7329385 (accessed on 15 May 2020).

23. Dickenson, N.C.; Krumholz, J.S.; Hunsucker, K.; Radicone, M. Iodine-infused aeration for hull fouling prevention: A vessel-scale study. Biofouling 2017, 33, 955-969. [CrossRef]

24. Subbiah, M.; Mitchell, S.M.; Ullman, J.L.; Call, D.R. Beta-lactams and florfenicol antibiotics remain bioactive in soils while ciprofloxacin, neomycin, and tetracycline are neutralized. Appl. Environ. Microbiol. 2011. [CrossRef]

25. Kawamura, T. The clinical course and laboratory data of hemorrhagic colitis caused by Escherichia coli O157:H7. Rinsho Byori. Jpn. J. Clin. Pathol. 1997, 45, 865-868.

26. Hayashi, T.; Makino, K.; Ohnishi, M.; Kurokawa, K.; Ishii, K.; Yokoyama, K.; Han, C.-G.; Ohtsubo, E.; Nakayama, K.; Murata, T.; et al. Complete Genome Sequence of Enterohemorrhagic Eschelichia coli O157:H7 and Genomic Comparison with a Laboratory Strain K-12. Curr. Neuropharmacol. 2001, 8, 11-22. [CrossRef]

27. Lederberg, J.; Tatum, E.L. Gene Recombination in Escherichia Coli. Nature 1946, 158, 558. [CrossRef]

28. Rice, D.H.; Hancock, D.D.; Roozen, P.M.; Szymanski, M.H.; Scheenstra, B.C.; Cady, K.M.; Besser, T.E.; Chudek, P.A. Household Contamination with Salmonella enterica1. Emerg. Infect. Dis. 2003, 9, 120-122. [CrossRef]

29. Cabral, J.P.S. Water Microbiology. Bacterial Pathogens and Water. Int. J. Environ. Res. Public Heal. 2010, 7, 3657-3703. [CrossRef]

30. Wei, L.; Wu, Q.; Zhang, J.; Guo, W.; Chen, M.; Xue, L.; Wang, J.; Ma, L. Prevalence and Genetic Diversity of Enterococcus faecalis Isolates from Mineral Water and Spring Water in China. Front. Microbiol. 2017, 8, 1109. [CrossRef] [PubMed] 
31. Chen, C.-Y.; Nace, G.W.; Irwin, P.L. A $6 \times 6$ drop plate method for simultaneous colony counting and MPN enumeration of Campylobacter jejuni, Listeria monocytogenes, and Escherichia coli. J. Microbiol. Methods 2003, 55, 475-479. [PubMed]

32. Boehm, A.B.; Sassoubre, L.M. Enterococci as indicators of environmental fecal contamination. In Enterococci: From Commensals to Leading Causes of Drug Resistant Infection; Gilmore, M.S., Clewell, D.B., Ike, Y., Shankar, N., Eds.; Eye and Ear Infirmary: Boston, MA, USA, 2014.

33. Ellis, K.; Van Vree, H. Iodine used as a water-disinfectant in turbid waters. Water Res. 1989, 23, $671-676$. [CrossRef]

34. Liang, Y.-M.; Zhang, Z.-L.; Yang, X.; Liu, W. Effect of Suspended Solids on the Sequential Disinfection of Secondary Effluent by UV Irradiation and Chlorination. J. Environ. Eng. 2013, 139, 1482-1487. [CrossRef]

35. McFadden, M.; Loconsole, J.; Schockling, A.; Nerenberg, R.; Pavissich, J.P. Comparing peracetic acid and hypochlorite for disinfection of combined sewer overflows: Effects of suspended-solids and $\mathrm{pH}$. Sci. Total Environ. 2017, 599, 533-539. [CrossRef] [PubMed]

36. Ellis, K.; Cotton, A.; Khowaja, M. Iodine disinfection of poor quality waters. Water Res. 1993, 27, 369-375. [CrossRef]

37. Deborde, M.; Von Gunten, U. Reactions of chlorine with inorganic and organic compounds during water treatment-Kinetics and mechanisms: A critical review. Water Res. 2008, 42, 13-51. [CrossRef]

38. Richardson, S.D.; Thruston, A.D.; Rav-Acha, C.; Groisman, L.; Popilevsky, I.; Juraev, O.; Glezer, V.; McKague, A.B.; Plewa, M.J.; Wagner, E.D. Tribromopyrrole, Brominated Acids, and Other Disinfection Byproducts Produced by Disinfection of Drinking Water Rich in Bromide. Environ. Sci. Technol. 2003, 37, 3782-3793. [CrossRef]

39. Smith, E.M.; Plewa, M.J.; Lindell, C.L.; Richardson, S.D.; Mitch, W.A. Comparison of Byproduct Formation in Waters Treated with Chlorine and Iodine: Relevance to Point-of-Use Treatment. Environ. Sci. Technol. 2010, 44, 8446-8452. [CrossRef]

40. Teng, X.; Shi, X.; Shan, Z.; Jin, Y.; Guan, H.; Li, Y.; Yang, F.; Wang, W.; Tong, Y.; Teng, W. Safe Range of Iodine Intake Levels: A Comparative Study of Thyroid Diseases in Three Women Population Cohorts with Slightly Different Iodine Intake Levels. Boil. Trace Elem. Res. 2007, 121, 23-30. [CrossRef]

41. Laurberg, P.; Pedersen, I.B.; Knudsen, N.; Ovesen, L.; Andersen, S. Environmental Iodine Intake Affects the Type of Nonmalignant Thyroid Disease. Thyroid 2001, 11, 457-469. [CrossRef] [PubMed]

42. Bulloch, M.N. Acute Iodine Toxicity From a Suspected Oral Methamphetamine Ingestion. Clin. Med. Insights Case Rep. 2014, 7, 127-129. [CrossRef] [PubMed]

43. Thomas, W.C.; Black, A.P.; Freund, G.; Kinman, R.N. Iodine Disinfection of Water. Arch. Environ. Heal. Int. J. 1969, 19, 124-128. [CrossRef]

44. Gupta, U.C.; Gupta, S. Trace element toxicity relationships to crop production and livestock and human health: Implications for management. Commun. Soil Sci. Plant Anal. 1998, 29, 1491-1522. [CrossRef]

45. WHO. Guidelines for Drinking-Water Quality, 2nd ed.; World Health Organization: Geneva, Switzerland, 1996; Volume 2.

46. Hetzel, B.S.; Maberly, G.F. 2 - Iodine. In Trace Elements in Human and Animal Nutrition, 5th ed.; Mertz, W., Ed.; Academic Press: San Diego, CA, USA, 1986; pp. 139-208.

47. In-Situ Shipboard Heat Exchanger Cleaning and Maintenance Using Innovative I2 Bubble Infusion Technology. Available online: https:/apps.dtic.mil/dtic/tr/fulltext/u2/a608227.pdf (accessed on 15 May 2020).

(C) 2020 by the authors. Licensee MDPI, Basel, Switzerland. This article is an open access article distributed under the terms and conditions of the Creative Commons Attribution (CC BY) license (http://creativecommons.org/licenses/by/4.0/). 